\title{
Electrochemical methods for probing DNA damage mechanisms and designing cisplatin-based combination chemotherapy
}

\author{
Zhi Li', Yael Zilberman', Qing-Bin Lu*,2 \& Xiaowu (Shirley) Tang*,1
}

\section{ABSTRACT}

An electrochemical approach was devised for detecting DNA damage and differentiating two DNA damage mechanisms, which is important to the design of new chemotherapeutics. This approach combined two platforms, based on the detection of base damage and DNA strand cleavage. In this work, our approach was demonstrated for the detection of cisplatin-induced DNA damage and the enhancement effects of two electron donors, $\mathrm{N}, \mathrm{N}, \mathrm{N}^{\prime}, \mathrm{N}^{\prime}$-tetramethyl-p-phenylenediamine (TMPD) and reduced graphene oxide ( $\mathrm{rGO}$ ). Our results demonstrated that TMPD enhanced DNA strand cleavage, supporting the proposed dissociative electron transfer mechanism. While rGO, which is an efficient electron donor, failed to show any enhancement (suggesting the lack of free-radical generation), overall, this electrochemical approach could be implemented for discovering next-generation DNA damage-based chemotherapy drugs.

\section{METHOD SUMMARY}

Our electrochemical approach contains two practical methods for detecting DNA damage induced by cisplatin and electron donorenhanced cisplatin (i.e., N,N,N',N'-tetramethyl$\mathrm{p}$-phenylenediamine and graphene oxide). One method detects base damage by directly measuring the G-base oxidation current using a glassy carbon electrode while the other detects the DNA strand cleavage by measuring the redox peak current and redox peak potential difference of $\left[\mathrm{Fe}(\mathrm{CN})_{6}\right]^{3-} /\left[\mathrm{Fe}(\mathrm{CN})_{6}\right]^{4-}$ using an ssDNA-functionalized Au working electrode.

\section{KEYWORDS:}

cisplatin • combination therapy • DNA damage - electrochemical analysis $\cdot$ reduced graphene oxide

'Department of Chemistry \& Waterloo Institute for Nanotechnology, University of Waterloo, 200 University Avenue West, Waterloo, ON N2L 3G1, Canada; ${ }^{2}$ Department of Physics \& Astronomy, University of Waterloo, 200 University Avenue West, Waterloo, ON N2L 3G1, Canada; *Author for correspondence:tangxw@ uwaterloo.ca

BioTechniques 66: 135-142 (March 2019) 10.2144/ btn-2018-0106
Recently, electrochemical detection of DNA damage has received particular attention for its advantages such as low cost, rapid detection and high sensitivity [1-3]. Kelley et al. demonstrated the ability to detect a single base DNA mismatch based on charge transduction through the DNA-modified electrode surface [4]. Diculescu et al. reported oxidative DNA damage detection using differential pulse voltammetry (DPV) [5]. BuČková et al. used redox species that specifically bind to double-stranded DNA for detecting double-stranded DNA disruption [6,7]. Hepel et al. investigated pre-mutagenic damage to DNA due to oxidative stress using electrochemical DNA sensors with redox indicators [8]. This group also employed DNA-coated electrodes with redox intercalators to study DNA damage caused by pesticides/herbicides [9]. The interaction between DNA and genotoxic agents was also successfully detected via an electrochemical method by monitoring DNA base oxidation signals [10-12]. In this work, we explored the possibility of using an electrochemical approach to not only detect DNA damage but also probe the underlying mechanisms, and we demonstrated its application in the design of Cis-diamminedichloroplatinum (II)-based combination chemotherapy.

Cis-diamminedichloroplatinum (II), or cisplatin, is the first platinum-based chemotherapy drug used to treat various types of cancers [13-15]. To date, scientists have synthesized over 3000 cisplatin derivatives, only two of which (oxaliplatin and carboplatin) have received FDA approval $[16,17]$. It is widely accepted that cisplatin's mode of action relies on bonding to DNA at the
N7 sites of adenine (A) or guanine $(G)$ base, generating intra- and inter-strand crosslinking [18]. Recently, Lu et al. have proposed another mechanism based on dissociative electron transfer (DET) $[19,20]$. In this mechanism, cisplatin accepts electrons from DNA bases, particularly $\mathrm{G}$ base, to form two reactive radicals (i.e., $\mathrm{Pt}(\mathrm{NH})_{2} \mathrm{Cl}$. and $\mathrm{Pt}(\mathrm{NH})_{2}$ :) that can lead to DNA cleavage. By applying the DET theory, one can design more effective chemotherapies by combining cisplatin with an electron donor [21].

An appropriate DNA damage detection method is necessary to verify the enhancement effect of an electron donor in cisplatin-based chemotherapy. Conventional methods include: gel electrophoresis [14], restriction enzyme assay [22,23], high-performance GC/MS [24] and ELISA [25]. In addition, fluorescent oligonucleotide molecular beacons were used for detection of single base polymorphism [26]. The surface-enhanced Raman scattering (SERS)-electrochemical method and the nanogrid DNA sensor were developed specifically to monitor DNA damage caused by chemotherapeutic drugs $[27,28]$. However, they all have various limitations/issues, including poor sensitivity, low accuracy, low efficiency and high cost (both time and money). So far, there are no electrochemical methods that detect cisplatin-induced DNA damage for the purposes of evaluating and designing cisplatin-based chemotherapy.

Graphene is a potential candidate to act as an electron donor due to its delocalized $\pi$-electrons. The electron transfer between graphene and various molecules has been well 
- studied through the surface doping of graphene [29-31]. Although the electron transfer reaction between cisplatin and graphene has never been demonstrated, there are some promising theoretical predictions. Through the density functional theory (DFT), Giovannetti et al. have demonstrated that electrons could be transferred from graphene to $\mathrm{Pt}$ due to the difference in graphene's Fermi level and Pt's electron affinity [32]. Considering the valence of Pt in cisplatin is $2^{+}$, it is reasonable to expect that electrons would be able to transfer from graphene to cisplatin.

Herein, we report an approach combining two electrochemical detection methods to detect DNA damage induced by cisplatin and the enhancement effects of two electron donors, N,N,N',N'-tetramethyl-pphenylenediamine (TMPD) and reduced graphene oxide ( $\mathrm{rGO}$ ). Overall, this work can lead to cost-effective tools for screening and designing new cisplatin-based chemotherapies.

\section{MATERIALS \& METHODS}

\section{Chemicals \& reagents}

Deoxyguanosine monophosphate (dGMP), cisplatin, 6-Mercapto-1-hexanol (MCH), hydrazine monohydrate, 2-(N-morpholino) ethanesulfonic acid (MES), graphite flakes, potassium persulfate, TMPD and poly(ethylene glycol) bis(amine) were purchased from Sigma-Aldrich and used without further purification. DNA oligomer (sequence: 5'-SH-AAAAAAAAACCCAGGTTCTCT) was purchased from Integrated DNA Technologies. Potassium ferricyanide $\left(\left[\mathrm{Fe}(\mathrm{CN})_{6}\right]^{3-}\right)$ and potassium ferrocyanide $\left(\left[\mathrm{Fe}(\mathrm{CN})_{6}{ }^{4-}\right)\right.$ were purchased from JT Baker. Phosphorus pentoxide was purchased from EMD. 1-Ethyl-3-(3-dimethylaminopropyl) carbodiimide (EDC) was purchased from GBiosciences. N-Hydroxysuccinimide (NHS) was purchased from Alfa Aesar.

Measurement of dGMP oxidation signal All dGMP solutions were prepared in $0.5 \mathrm{M}$ acetate buffer ( $\mathrm{pH}$ 5.0). dGMP solutions with concentrations of 0 (as background current), 100,300 and $500 \mu \mathrm{M}$, and $1 \mathrm{mM}$ were used to generate a calibration curve. To detect cisplatin-induced DNA damage, cyclic voltammetry (CV) spectra were recorded after incubating various concentrations of dGMP with $500 \mu \mathrm{M}$ cisplatin (with or without
$1 \mathrm{mM}$ TMPD) for $0,5,10,24$ and $48 \mathrm{~h}$ at room temperature. Before each test, the glassy carbon electrode (GCE; CHI104; CH Instruments) was sequentially polished using 1 , 0.3 and $0.05 \mu \mathrm{m}$ alumina with careful rinsing between each polish followed by a final gentle sonication in a $30 \%$ ethanol solution for $5 \mathrm{~min}$ to clean the electrode surface. To improve reproducibility, the polished GCE was electrochemically activated by cycling in a $0.5 \mathrm{M} \mathrm{H}_{2} \mathrm{SO}_{4}$ solution from $-0.5 \mathrm{~V}$ to $1.5 \mathrm{~V}$ at a scan rate of $0.1 \mathrm{~V} / \mathrm{s}$ until stable CV curves were obtained. The silver/silver chloride $(\mathrm{Ag} / \mathrm{AgCl})$ electrode was used as the reference electrode through the entire study, unless otherwise indicated. CV curves of the prepared dGMP solutions were recorded from $0.4 \mathrm{~V}$ to $1.2 \mathrm{~V}$ at a scan rate of $0.01 \mathrm{~V} / \mathrm{s}$ using a potentiostat $(\mathrm{CHI650} ; \mathrm{CH}$ Instruments) and a three-electrode system. All the CV results were presented following the polarographic convention in this report.

\section{Surface modification of Au electrode with SsDNA}

The Au electrode (CHI101; $\mathrm{CH}$ Instruments) was treated with piranha solution for $20 \mathrm{~min}$, followed by rinsing with Milli-Q water. The treated electrode was then polished, cleaned and electrochemically activated using the same aforementioned procedure for GCE. The Au electrode was then incubated in $3 \mu \mathrm{M}$ thiol-terminated single-stranded DNA (ssDNA) solution for $4 \mathrm{~h}$, followed by $1 \mathrm{~h}$ of treatment in a $1 \mathrm{mM}$ $\mathrm{MCH}$ solution to remove the loosely bound DNA strands. The ssDNA-Au electrode was kept in water for future use.

\section{Electrochemical measurement using ssDNA-Au electrode}

CV curves of $5 \mathrm{mM}\left[\mathrm{Fe}(\mathrm{CN})_{6}\right]^{3-/}\left[\mathrm{Fe}(\mathrm{CN})_{6}\right]^{4-}$ were recorded using the cleaned bare $\mathrm{Au}$ electrode and the ssDNA-Au electrode with a potential range from $-0.2 \mathrm{~V}$ to $0.6 \mathrm{~V}$ and $\mathrm{a}$ scan rate of $0.01 \mathrm{~V} / \mathrm{s}$. To detect cisplatininduced DNA damage, CV curves were acquired after treating the ssDNA-Au electrode with $500 \mu \mathrm{M}$ cisplatin solution (with or without $1 \mathrm{mM}$ TMPD) for 0, 2, 4, 8 and $19 \mathrm{~h}$.

\section{Elemental analysis of ssDNA-Au surface}

A piece of Au-coated silicon wafer was prepared and used for further DNA modifi- cation. The prepared Au surface was rinsed with acetone, isopropanol (IPA) and Milli-Q water in sequence and blow-dried with nitrogen. The Au surface was then modified using $3 \mu \mathrm{M}$ thiol-terminated ssDNA solution to make the DNA-modified Au surface. Half of the silicon wafer was incubated in a $500 \mu \mathrm{M}$ cisplatin solution for $8 \mathrm{~h}$ and rinsed with Milli-Q water. XPS characterization (ESCALAB 250Xi; Thermo Scientific) was performed in the N 1s, P 2p, Au $4 \mathrm{f}$ and $\mathrm{Pt} 4 \mathrm{f}$ regions. All XPS spectra were analyzed using the CasaXPS software.

\section{Synthesis of GO \& rGO}

Graphene oxide (GO) was synthesized using a modified Hummer's method as reported previously [33-35]. rGO was then synthesized by reducing $\mathrm{GO}$ with hydrazine [36]. This method was expected to preserve the carboxylic acid groups on GO, while reducing the other oxidative defects. The $\mathrm{GO}$ solution was first diluted to a concentration of $2 \mathrm{mg} / \mathrm{ml}$, and then added to a solution $(7.5 \mathrm{ml})$ of $1.4 \mathrm{mg} / \mathrm{ml}$ hydrazine and $11.2 \mathrm{mg} / \mathrm{ml}$ ammonium. The reaction continued for $1 \mathrm{~h}$ in a water bath at $95^{\circ} \mathrm{C}$. The resulting dispersion was dialyzed using Milli-Q water to remove the excess hydrazine for 5 days with water change every $4 \mathrm{~h}$.

\section{Characterizations of GO \& rGO}

The UV-vis spectra of GO $(75 \mu \mathrm{g} / \mathrm{ml})$ and rGO $(25 \mu \mathrm{g} / \mathrm{ml})$ solutions were recorded from $200 \mathrm{~nm}$ to $900 \mathrm{~nm}$ using a spectrophotometer (DU 530; Beckman Coulter Life Science). The atomic force microscopy (AFM) images were collected using a Digital Instruments Nanoscope Multimode AFM (Multimode-8; Bruker) with tapping mode.

\section{PEGylation of rGO}

rGO was functionalized with linear amineterminated PEG (PEG-NH $\mathrm{NH}_{3}$ ) through carbodiimide chemistry. Briefly, $10 \mathrm{ml}$ of $1 \mathrm{mg} / \mathrm{ml} \mathrm{rGO}$ solution was added to $5 \mathrm{ml}$ of 2-(N-morpholino)ethanesulfonic acid (MES) buffer containing 20 mg of PEG- $\mathrm{NH}_{3}$ with excess EDC and NHS. The mixture was constantly stirred overnight at room temperature, followed by 3 days of dialysis with water change every $4 \mathrm{~h}$. The dialyzed solution was centrifuge-filtered and re-dissolved until a final concentration of $1.5 \mathrm{mg} / \mathrm{ml}$. 
Electrochemical study of DNA damage using PEG-rGO as the electron donor

Electrochemical measurements were performed in the same manner as described above. Instead of $1 \mathrm{mM}$ TMPD, 0.15 or $0.75 \mathrm{mg} / \mathrm{ml}$ PEG-rGO was used for the measurement of dGMP oxidation, and $1.3 \mathrm{mg} / \mathrm{ml}$ PEG-rGO was used when generating $\mathrm{CV}$ curves using the ssDNA-Au electrode.

\section{RESULTS \& DISCUSSION}

Electrochemical methods for measuring cisplatin-induced DNA damage

Figure 1 shows schematically the two electrochemical methods used in this work. The first method directly measures the oxidation signal of dGMP on a GCE surface. The reduction of this oxidation signal indicates that the bonding of cisplatin to the $\mathrm{G}$ base inhibits the oxidation of dGMP electrochemically (Figure 1A). The second method uses a ssDNA-Au working electrode to measure the redox of the ferricyanide/ferrocyanide pair $\left(\left[\mathrm{Fe}(\mathrm{CN})_{6}\right]^{3-} /\right.$ $\left.\left[\mathrm{Fe}(\mathrm{CN})_{6}\right]^{4}\right)$. The negative charge of ssDNAs on the $\mathrm{Au}$ electrode electrostatically repulses the $\left(\left[\mathrm{Fe}(\mathrm{CN})_{6}\right]^{3-} /\left[\mathrm{Fe}(\mathrm{CN})_{6}\right]^{4-}\right)$ ions away from the electrode surface and thus suppresses the redox signal. Cisplatininduced DNA cleavage reduced the amount of negative charge on the Au electrode and recovered the redox signal (Figure 1B). The addition of TMPD augmented the cisplatininduced damage and the redox signal. Combining the two methods, we can probe the two different DNA damage mechanisms - base damage and strand cleavage.

\section{Suppression of dGMP oxidation signal by cisplatin/TMPD}

Figure 2A shows the CV curves of dGMP at different concentrations. These curves have oxidation peaks at approximately $1.00-1.02 \mathrm{~V}$, but no reduction peak, which is consistent with previous literature reports that stated the oxidation is irreversible [37]. In addition, there is a linear relationship between the oxidation peak current intensity $\left(I_{p}\right)$ and dGMP concentration, as shown in Figure 2B. Upon the introduction of $500 \mu \mathrm{M}$ cisplatin, the absolute value of $I_{p}$ decreased over time (Figure $2 \mathrm{C}$ ). After $5 \mathrm{~h}$ of incubation, it dropped from 10.42 to $9.61 \mu \mathrm{A}$. After $48 \mathrm{~h}$ of incubation, it decreased to $5.2 \mu \mathrm{A}$. The observed decrease in $I_{p}$ can be attributed to cisplatin-induced damage to the G-base, as expected [23].

We also examined the effect of adding TMPD into the system. According to previous reports [21], TMPD as an electron donor can generate reactive radicals to enhance DNA damage through the following reaction:

Figure 2D \& E show that the addition of TMPD led to a similar trend over time compared to cisplatin alone, with slightly increased current intensities. However, according to the reaction kinetics (Figure 2F),

$$
\mathrm{TMPD}+\mathrm{Pt}\left(\mathrm{NH}_{3}\right)_{2} \mathrm{Cl}_{2} \rightarrow \mathrm{TMPD}^{+}: \mathrm{Cl}^{-}+\mathrm{Pt}\left(\mathrm{NH}_{3}\right)_{2} \mathrm{Cl}
$$

which showed that the slope remained similiar, the conclusion is that TMPD did not accelerate dGMP base damage.

We then studied the effect of excessive TMPD on cisplatin performance. $500 \mu \mathrm{M}$ dGMP was mixed with various concentrations of cisplatin with or without $1 \mathrm{mM}$ TMPD. As shown in Supplementary Figure S1, excessive TMPD did not make a difference. One explanation for the lack of the enhancement effect of TMPD on dGMP oxidation could be because TMPD is easily auto-ionized in water as a result of its low ionization potential $[38,39]$. However in the work of Luo et al. it was shown that the combination of cisplatin and TMPD as a drug therapy in an aqueous environment enhanced DNA damage and led to a higher percentage of cell lysis [21]. Therefore, our results suggest that TMPD did not promote DNA base damage and the combination effect of TMPD and cisplatin, as observed in previous studies, might be due to enhanced DNA strand cleavage instead.

\section{DNA damage on SSDNA-Au electrode}

Figure $3 A$ shows the $C V$ curves of $5 \mathrm{mM}$ $\left[\mathrm{Fe}(\mathrm{CN})_{6}\right]^{3-} /\left[\mathrm{Fe}(\mathrm{CN})_{6}\right]^{4-}$ acquired using a bare $\mathrm{Au}$ electrode and a ssDNA-Au electrode without cisplatin treatment. For bare $\mathrm{Au}$ electrode, we observed a relatively small redox peak potential difference $(\Delta E p)$ and a high oxidation peak current intensity $\left(I_{p c}\right)$. Upon modification with ssDNA, the $I_{p c}$ value dropped and $\triangle E p$ increased. This behavior can be well explained by the electrostatic repulsion between $\left[\mathrm{Fe}(\mathrm{CN})_{6}\right]^{3-/}\left[\mathrm{Fe}(\mathrm{CN})_{6}\right]^{4-}$ anions and the ssDNA strands on the electrode surface, which reduces surface density of redox species as well as slowing down electron transfer. Upon introducing cisplatin, $I_{p c}$ recovered partially and $\Delta E p$ became smaller (Figure 3B). Hence, we can conclude that cisplatin reduced the amount of negative charge on the electrode surface. Moreover, the addition of TMPD further enhanced redox signal recovery (Figure 3B-D). Table 1 shows the $I_{p c}$ and $\triangle E p$ values for all four sample groups bare Au electrode, ssDNA-Au without cisplatin treatment, ssDNA-Au after cisplatin treatment for $8 \mathrm{~h}$, and ssDNA-Au after the combined treatment of

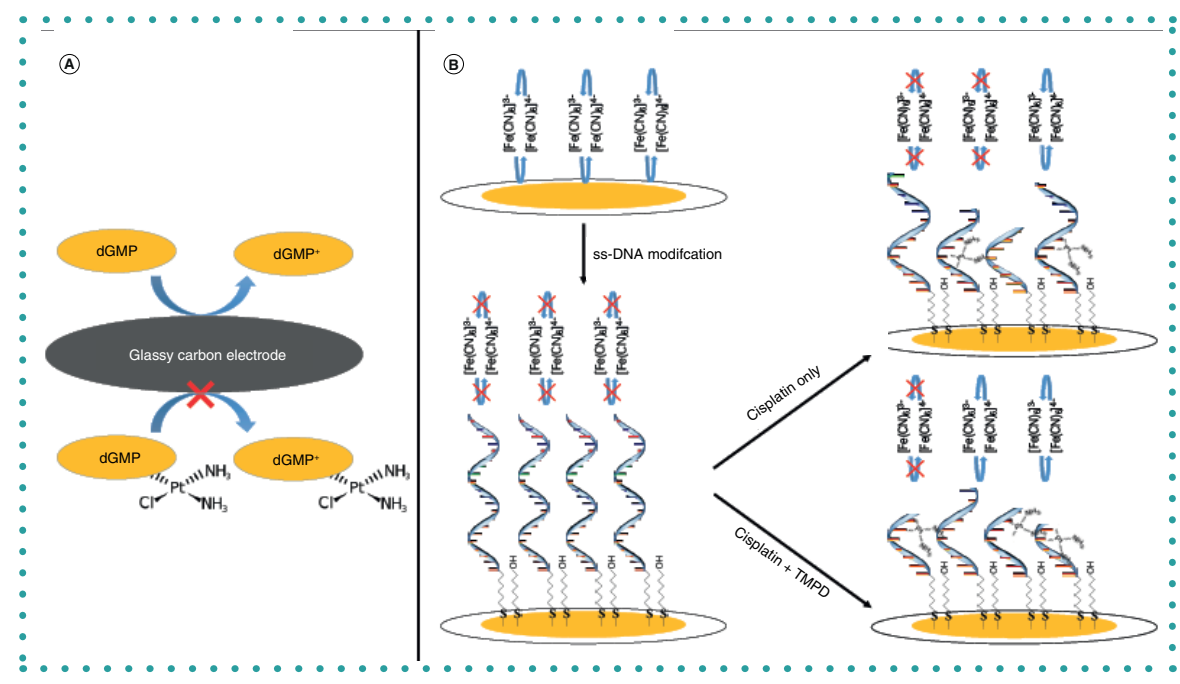

Figure 1. Schematic drawings of the two DNA damage mechanism. (A) Cisplatin inhibits the oxidation of dGMP on glassy carbon electrode. (B) Cisplatin leads to the recovery of $\left[\mathrm{Fe}(\mathrm{CN})_{6}\right]^{3-1}$ $\left[\mathrm{Fe}(\mathrm{CN})_{6}\right]^{4-}$ redox signal on ss-DNA-Au electrode while the combination of cisplatin/TMPD enhances the effect further. ss-DNA: Single stranded DNA; TMPD: N,N,N',N'-tetramethyl-p-phenylenediamine. 

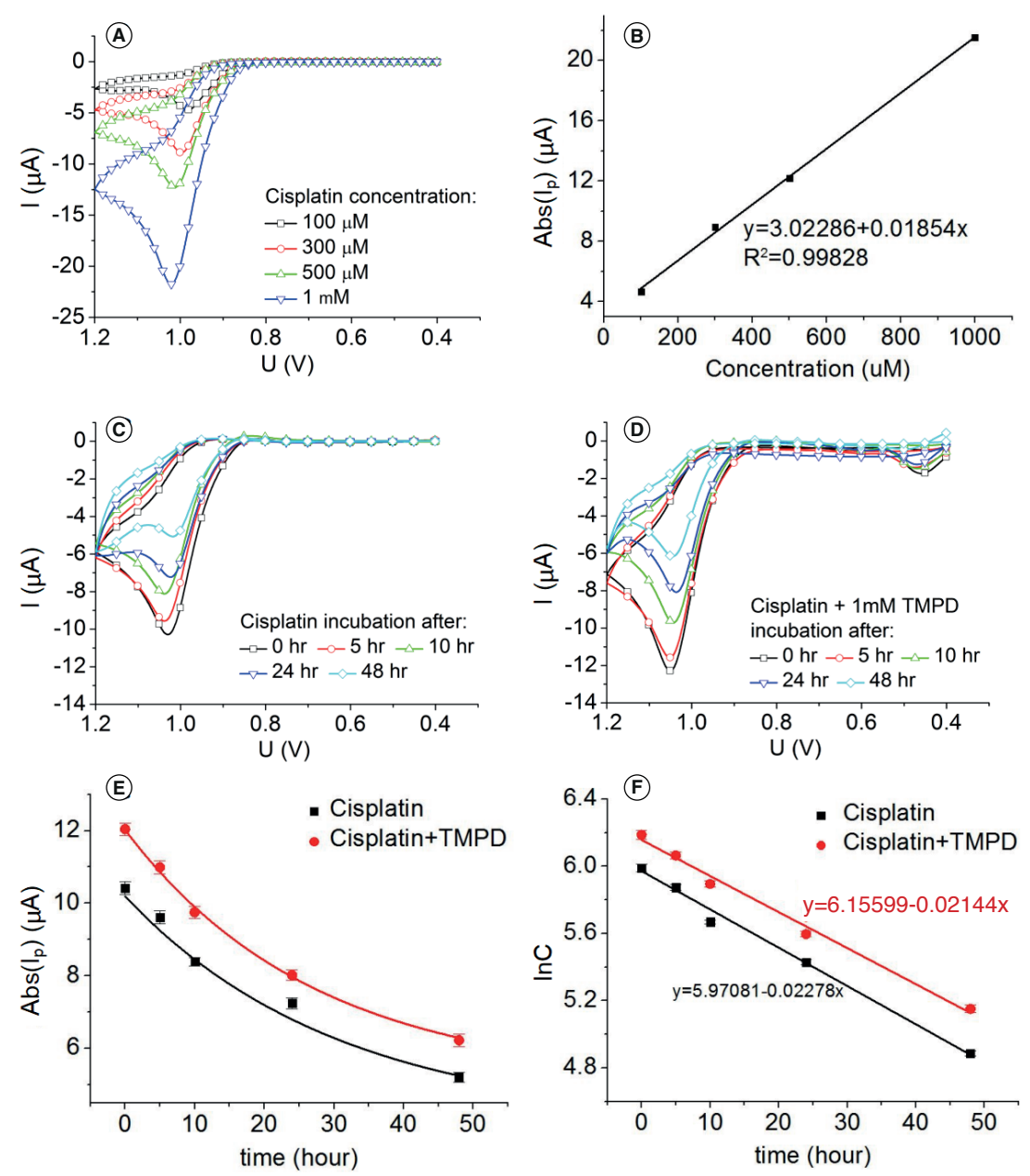

Figure 2. Suppression of dGMP oxidation signal by cisplatin/TMPD. (A) Cyclic voltammetry (CV) of dGMP at various concentrations (scan rate: $20 \mathrm{mV} / \mathrm{s}$ ). (B) Absolute value of dGMP oxidation peak current $\left(\mathrm{I}_{\mathrm{p}}\right)$ versus dGMP concentration. CV curves of dGMP mixed with (C) $500 \mu \mathrm{M}$ cisplatin and (d) $500 \mu \mathrm{M}$ cisplatin $+1 \mathrm{mM}$ TMPD after 0, 5, 10, 24 and $48 \mathrm{~h}$ (scan rate: $20 \mathrm{mV} / \mathrm{s}$ ). (E) Absolute $\mathrm{I}_{\mathrm{p}}$ intensity and (F) reaction kinetics of $500 \mu \mathrm{M}$ dGMP mixed with $500 \mu \mathrm{M}$ cisplatin and $500 \mu \mathrm{M}$ cisplatin $+1 \mathrm{mM}$ TMPD over time. The error bars represent the standard deviation of measurements from three repetitions.

TMPD: N,N,N',N'-tetramethyl-p-phenylenediamine.

cisplatin/TMPD for $8 \mathrm{~h}$. The recorded $I_{p c}$ using the ssDNA-Au working electrode increased by $6 \%$ compared to the one recorded by a bare Au electrode, $58 \%$ after cisplatin treatment and $72 \%$ after cisplatin/TMPD combination treatment. We also treated the ssDNA-Au electrode with TMPD alone, which had no effect on the redox signal (Supplementary Figure S2). The trends in $I_{p c}$ and $\Delta E p$ evidently illustrate that combining TMPD with cisplatin enhanced DNA damage, but TMPD by itself does not. Combining this result with the fact that TMPD did not enhance G-base damage (as shown in Figure 2), we thus conclude that TMPD enhanced cisplatin-induced DNA strand cleavage due to DET.

\section{Elemental analysis of ssDNA-Au electrode upon cisplatin treatment}

We further verified the interactions between cisplatin and DNA through XPS analysis. Figure 4 shows the $\mathrm{Au}, \mathrm{Pt}, \mathrm{N}$ and $P$ peaks in the XPS spectra of the ssDNAAu surface, with and without cisplatin treatment. The percentages of these four elements on the surface were extracted from the spectra and listed in Table 2. After cisplatin treatment, Au decreased by $7.00 \%, \mathrm{Pt}$ and $\mathrm{N}$ increased by 3.62 and $4.42 \%$, respectively (Figure 3 \& Table 2 ), supporting the DNA base damage mechanism, where cisplatin (containing Pt and N) bonds to G-base. Furthermore, we also calculated the 'expected' percentages of $\mathrm{N}$ and $\mathrm{P}$ after cisplatin treatment, assuming no DNA cleavage. The actual experimental values were lower than the 'expected' (23.33 vs $24.36 \%$ for $N$, and 5.73 vs $6.13 \%$ for $P$, as shown in Supplementary Table S1). The difference between these values supported the proposed DNA strand cleavage mechanism. In addition, we observed shifts of $\mathrm{N}$ and $\mathrm{P}$ peaks toward lower binding energies (Figures 4C-D), indicating that the ssDNA density on the surface changed from high to low as previously reported [40]. Overall, the XPS data evidently support that cisplatin induced both DNA base damage and strand cleavage.

\section{Effects of r'GO on cisplatin treatment}

Subsequently, we synthesized GO and rGO (Supplementary Figures S3 \& S4) and explored rGO as a substitute for TMPD to act as an electron donor to cisplatin. Figures $5 A \& B$ show the AFM images of our GO and rGO sheets on freshly cleaved mica substrates. The lateral size of $\mathrm{GO}$ and $\mathrm{rGO}$ ranged from hundreds of nanometers to several micrometers. Figures 5C-D show that the thicknesses were $\sim 1.1 \mathrm{~nm}$ for $\mathrm{GO}$, and $\sim 0.7 \mathrm{~nm}$ for $\mathrm{rGO}$, indicating that they are single-layer nanostructures.

We used carbodiimide chemistry to modify rGO with PEG and produced PEG-rGO to improve its biocompatibility and solubility in physiological buffer (Supplementary Figure S5) [41]. We measured redox signals of $\left[\mathrm{Fe}(\mathrm{CN})_{6}\right]^{3-} /$ $\left[\mathrm{Fe}(\mathrm{CN})_{6}\right]^{4-}$ on a ssDNA-Au electrode, which showed minor difference between cisplatin alone and cisplatin combined with PEG-rGO (Figure 6A \& B). We found that PEG-rGO also did not promote dGMP damage (Supplemetnary Figure S6). We suspect that the formation of stable cisplatin-rGO complex could be the reason for the lack of enhanced DNA damage. Although efficient electron transfer between graphene and cisplatin is predicted, the adsorption of cisplatin on rGO [42] might have inhibited the generation of free radicals and/or prevented 
the radicals from attacking the DNAs. The PEGylation of rGO could have also hindered DET occurence of between rGO and cisplatin. Thus, our results from the electrochemical analysis suggest that improved $\mathrm{GO}$ reduction and $\mathrm{rGO}$ modification methods are needed before rGO can be integrated as an effective electron donor for cisplatin combination therapy.

In this work, we introduced an electrochemical approach by combining two methods for measuring DNA damage. The first method relies on signal reduction of dGMP oxidation caused by base damage. The second method detects the recovery of $\left[\mathrm{Fe}(\mathrm{CN})_{6}\right]^{3-/}\left[\mathrm{Fe}(\mathrm{CN})_{6}\right]^{4-}$ redox signals due to SsDNA strand cleavage. Using this electrochemical approach, we were able to demonstrate that cisplatin induced DNA damage via both base damage and strand cleavage mechanisms. Furthermore, TMPD, an electron donor used in cisplatin combination therapy, enhanced the DNA strand cleavage but not base damage. On the other hand, although rGO was predicted to have efficient DET with cisplatin, it failed to show enhanced DNA damage, suggesting the lack of cisplatin radical generation. Overall, we envision that the reported electrochemical approach will be a powerful tool to assist in developing, and particularly pre-screening of, new DNA damage-based chemotherapies.
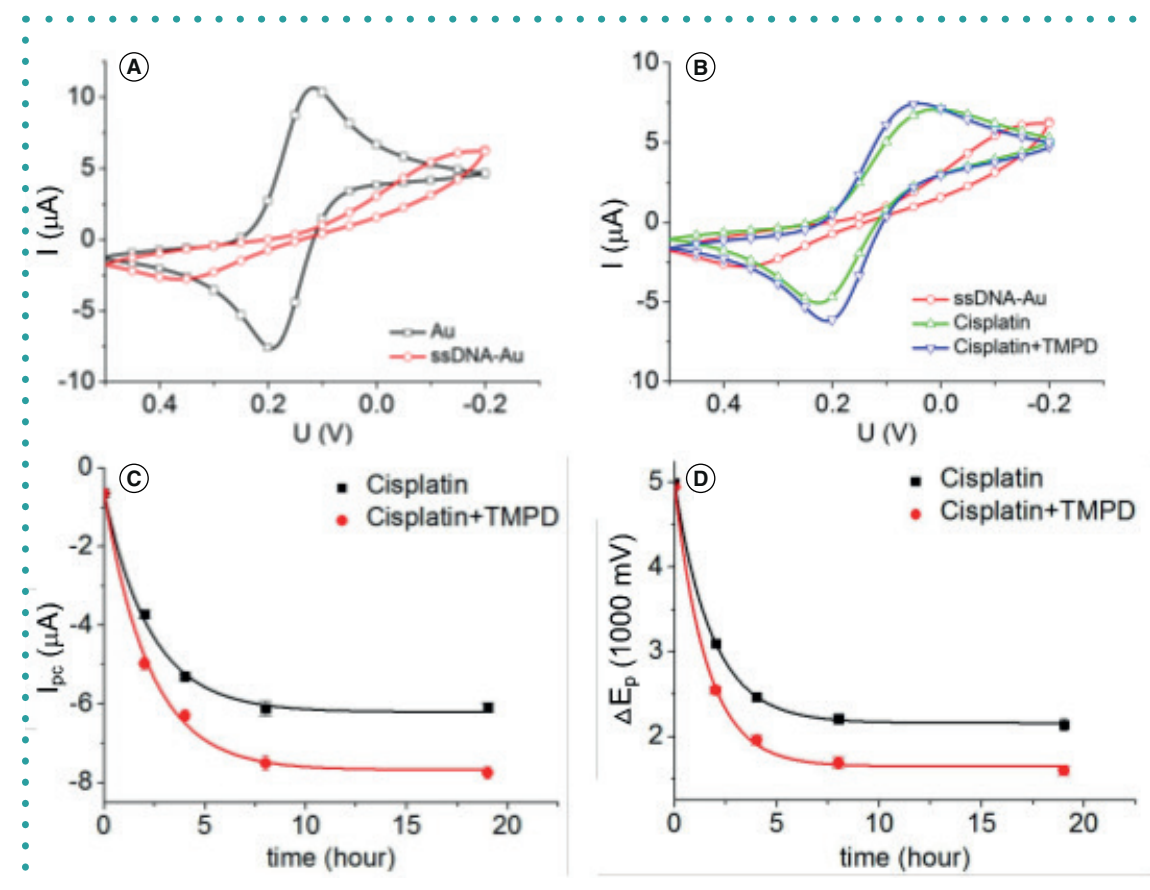

Figure 3. DNA strand cleavage induced by cisplatin/TMPD. (A) Cyclic voltammetry (CV) curves of $\left[\mathrm{Fe}(\mathrm{CN})_{6}\right]^{3-} /\left[\mathrm{Fe}(\mathrm{CN})_{6}\right]^{4-}$ recorded using bare $\mathrm{Au}$ and ssDNA-Au working electrodes. (B) CV curves of $\left[\mathrm{Fe}(\mathrm{CN})_{6}\right]^{3-} /\left[\mathrm{Fe}(\mathrm{CN})_{6}\right]^{4-}$ recorded using an ssDNA-Au electrode before and after $8 \mathrm{~h}$ of treatment with $500 \mu \mathrm{M}$ cisplatin, $500 \mu \mathrm{M}$ cisplatin $+1 \mathrm{mM}$ TMPD. (C) $\mathrm{I}_{\mathrm{pc}}$ and (D) $\Delta \mathrm{E}_{\mathrm{p}}$ of $\left[\mathrm{Fe}(\mathrm{CN})_{6}\right]^{3-} /\left[\mathrm{Fe}(\mathrm{CN})_{6}\right]^{4-}$ recorded using the ssDNA-Au electrode treated by $500 \mu \mathrm{M}$ cisplatin, $500 \mu \mathrm{M}$ cisplatin $+1 \mathrm{mM}$ TMPD over time. The error bars represent the standard deviation of measurements from three repetitions. $\mathrm{I}_{\mathrm{pc}}$ : Oxidation peak current intensity; ssDNA: Single stranded DNA; TMPD: N,N,N',N'-tetramethyl-pphenylenediamine.

\section{FUTURE PERSPECTIVE}

DNA damage detection is a vital pathway for screening anti-cancer drugs. Nowadays, restriction enzyme or fluores- cence-based techniques are commonly used to detect DNA damage; however they have drawbacks such as poor sensitivity and high cost (both time and money).

\begin{tabular}{|c|c|c|}
\hline Electrode & $I_{p c}(\mu \mathbf{A})$ & $\Delta E_{p}(\mathbf{m V})$ \\
\hline Bare Au & 10.45 & 74 \\
\hline ssDNA-Au & 0.64 & 499 \\
\hline ssDNA-Au, cisplatin & 6.11 & 221 \\
\hline ssDNA-Au, cisplatin + TMPD & 7.50 & 169 \\
\hline
\end{tabular}

Table 2. Percentages of each element on the single stranded DNA-modified Au surface with and without cisplatin treatment.

\section{Element}

\begin{tabular}{|l|}
\hline Au \\
\hline Pt \\
\hline N \\
\hline P \\
\hline
\end{tabular}

Cisplatin treatment

\begin{tabular}{|l|l|}
\hline Without & With \\
\hline $74.0 \%$ & $67.0 \%$ \\
\hline $0.3 \%$ & $3.9 \%$ \\
\hline $18.9 \%$ & $23.3 \%$ \\
\hline $6.8 \%$ & $5.7 \%$ \\
\hline
\end{tabular}



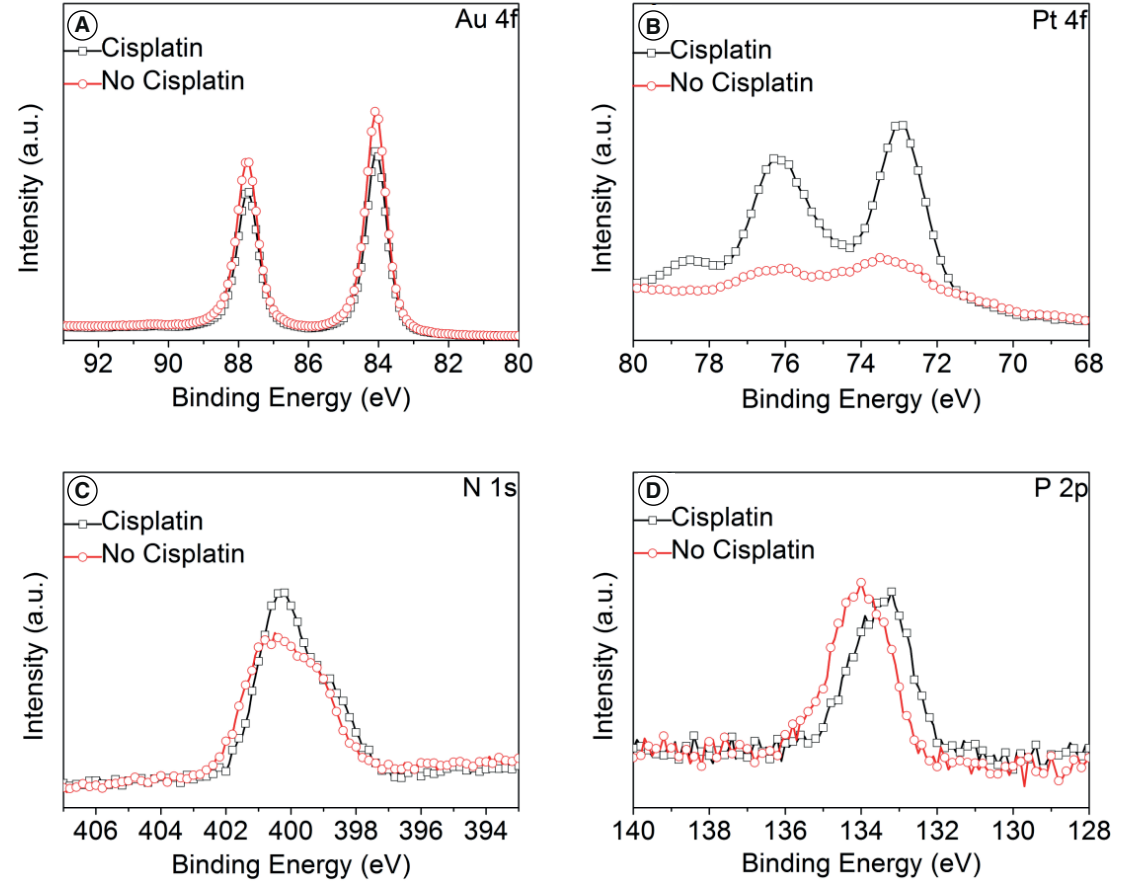

Figure 4. Elemental analysis of single stranded DNA-Au electrode upon cisplatin treatment. The high-resolution XPS spectra of the ssDNA-Au surface with and without cisplatin treatment correspond to (A) Au 4f, (B) Pt 4f, (C) N 1s and (D) P 2p.
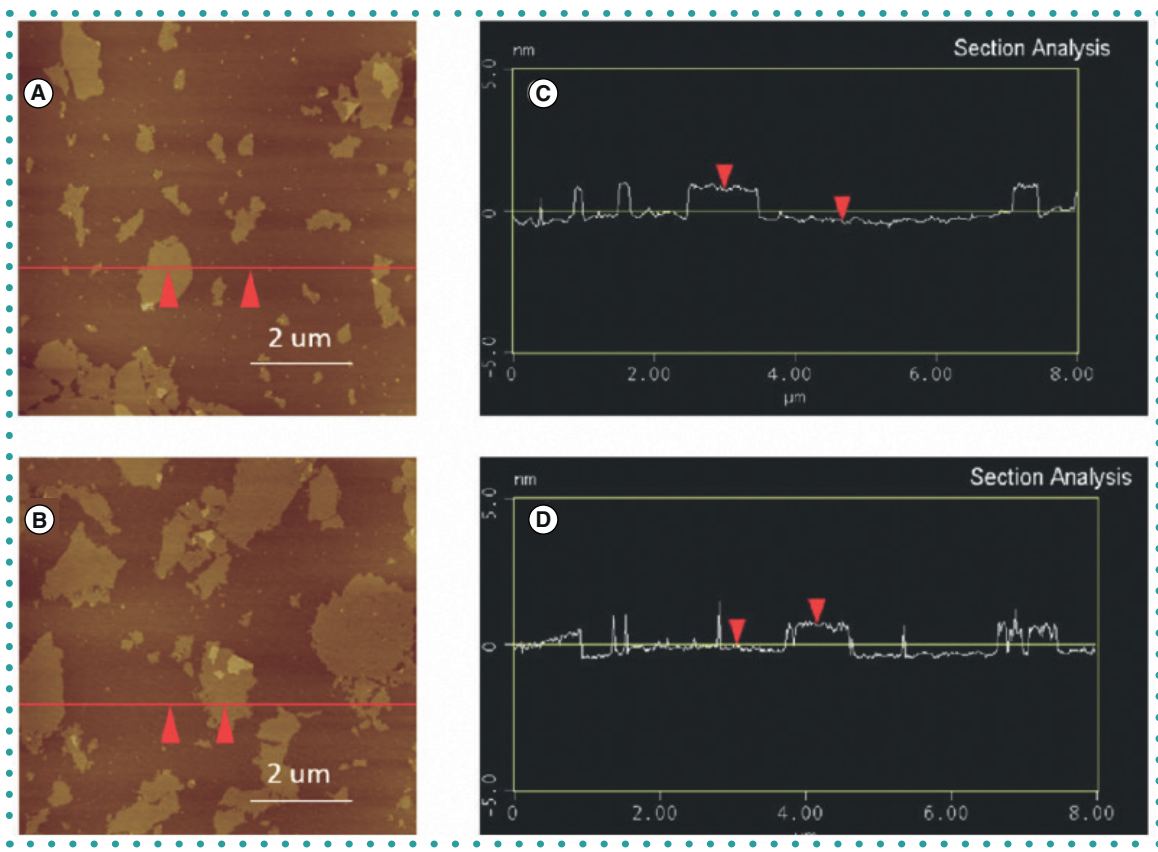

Figure 5. Atomic force microscopy images and analysis of the modified graphene oxide nanostructure. Atomic force microscopy images of (A) graphene oxide (GO) and (B) reduced (r)GO. Section analysis of (C) GO and (D) rGO. The red arrows and red lines indicate the locations of the scan.

- The need for a high-throughput, automated and sensitive assay for efficient drug screening and discovery still remains unresolved. In this report, we devised an electrochemical approach to the design and fabrication of a highthroughput tool, consisting of an array of screen-printed electrodes, for screening DNA damaging agents. In addition, future studies will be conducted in complex media such as blood or plasma in contrast to the current study, which was conducted in buffer solutions. The electrochemical approach developed in this study will also be used to discover new nanoparticulated electron donors, such as rGO.

\section{AUTHOR CONTRIBUTIONS}

Conception and design of study: Zhi Li, Qing-Bin Lu, Xiaowu (Shirley) Tang. Acquisition of data: Zhi Li. Analysis and/or interpretation of data: Zhi Li, Yael Zilberman. Drafting the manuscript: $\mathrm{Zhi} \mathrm{Li}$, Yael Zilberman. Revising the manuscript critically for important intellectual content: Zhi Li, Yael Zilberman, Xiaowu (Shirley) Tang. Approval of the version of the manuscript to be published: Zhi Li, Yael Zilberman, Qing-Bin Lu, Xiaowu (Shirley) Tang.

\section{FINANCIAL \& COMPETING INTERESTS DISCLOSURE}

This work was supported by an operating grant to QBL from the Canadian Institutes of Health Research (CIHR) and Discovery grants to QBL and ST from the Natural Science and Engineering Research Council of Canada (NSERC). The authors have no other relevant affiliations or financial involvement with any organization or entity with a financial interest in or financial conflict with the subject matter or materials discussed in the manuscript apart from those disclosed.

No writing assistance was utilized in the production of this manuscript.

\section{ACKNOWLEDGMENTS}

We thank Dr Juewen Liu for providing the single strand DNA. We thank Louis Cheung from the Shirley Tang group for sharing the graphene oxide solution. We thank William Qin for reviewing the manuscript.

\section{OPEN ACCESS}

This work is licensed under the AttributionNonCommercial-NoDerivatives 4.0 Unported License. To view a copy of this license, visit http://creativecommons.org/ licenses/by-nc-nd/4.0/ 


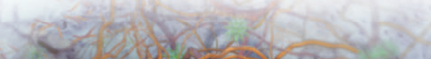

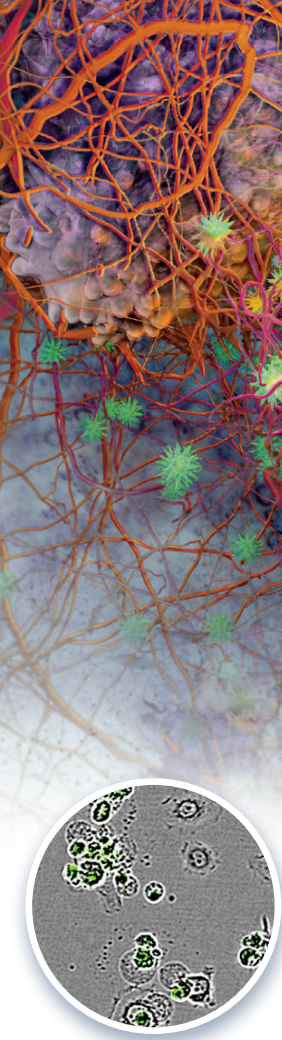

Apoptosis

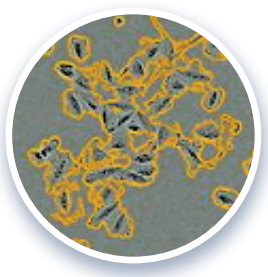

Proliferation

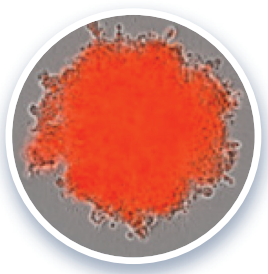

Spheroids
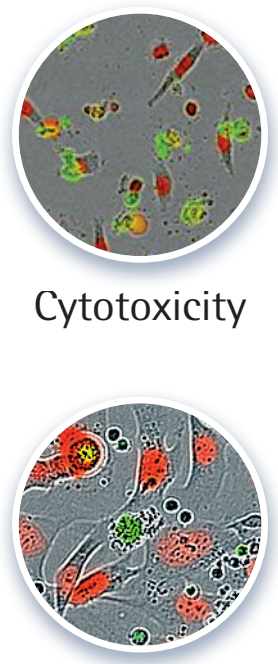

Immune-cell

killing

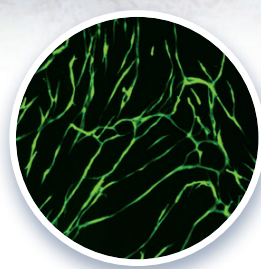

Angiogenesis

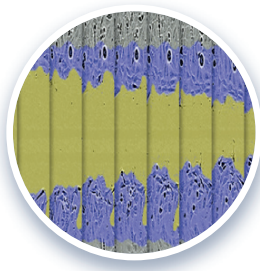

Cell Migration and Invasion

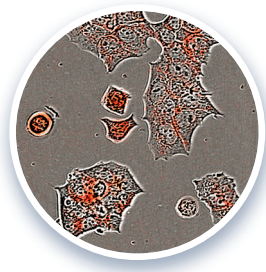

Antibody Internalization

\section{Exploring hallmarks of cancer with real-time live-cell analysis}

IncuCyte ${ }^{\circledR}$ S3 Live-Cell Analysis System is revolutionizing the field of Oncology research. Scientists around the world are studying cancer cell biology, non-invasively and in real-time, to gain unique insights using advanced cell models.

- Cancer Stem Biology

- 3D models

- Immuno-oncology

Discover more at

Essenbio.com/oncology

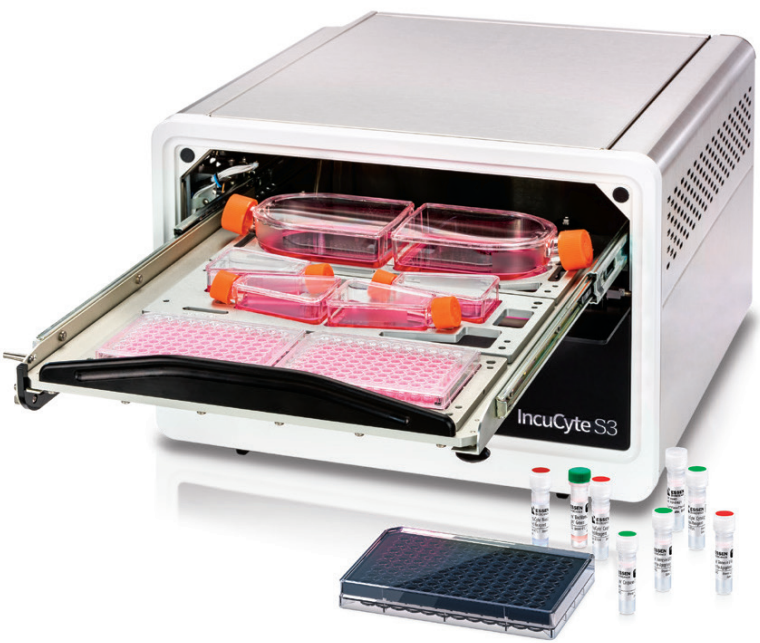

IncuCyte

A SARTORIUS BRAND 


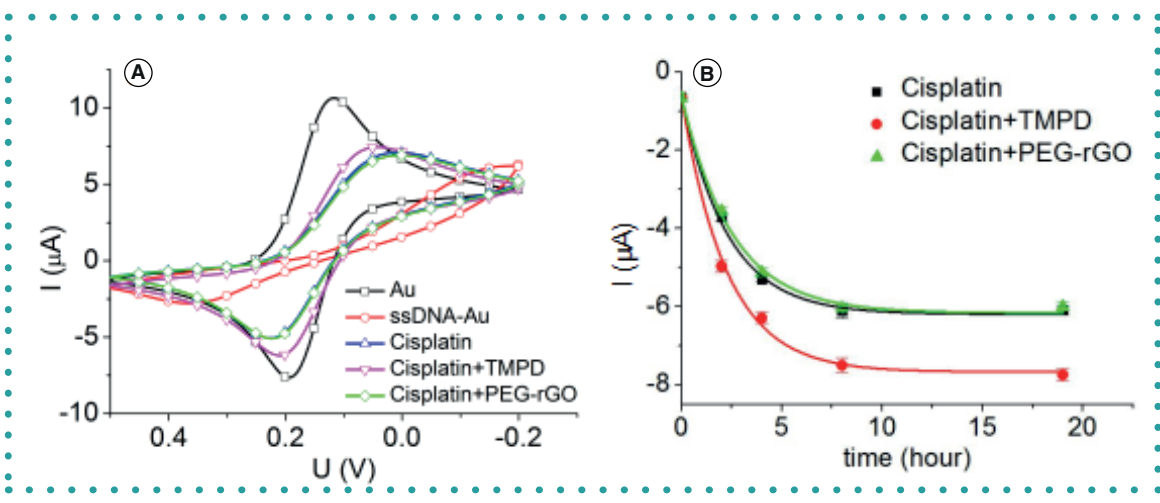

Figure 6. Effects of reduced graphene oxide on cisplatin treatment. (A) Cyclic voltammetry (CV) curves of $\left[\mathrm{Fe}(\mathrm{CN})_{6}\right]^{3-} /\left[\mathrm{Fe}(\mathrm{CN})_{6}\right]^{4-}$ recorded using bare $\mathrm{Au}$, single stranded DNA-Au electrodes without treatment, ssDNA-Au after $8 \mathrm{~h}$-treatment with $500 \mu \mathrm{M}$ cisplatin, $500 \mu \mathrm{M}$ cisplatin $+1 \mathrm{mM}$ TMPD and $500 \mu \mathrm{M}$ cisplatin $+1.3 \mathrm{mg} / \mathrm{ml} \mathrm{PEG-rGO}$. (B) The $\mathrm{I}_{\mathrm{pc}}$ value of $\left[\mathrm{Fe}(\mathrm{CN})_{6}\right]^{3-} /\left[\mathrm{Fe}(\mathrm{CN})_{6}\right]^{4-}$ at various time points after treatment with $500 \mu \mathrm{M}$ cisplatin, $500 \mu \mathrm{M}$ cisplatin $+1 \mathrm{mM}$ TMPD and $500 \mu \mathrm{M}$ cisplatin $+1.3 \mathrm{mg} / \mathrm{ml} \mathrm{PEG-rGO}$.

$\mathrm{I}_{\mathrm{pc}}$ : Oxidation peak current intensity; rGO: Reduced graphene oxide; TMPD: N,N,N',N'-tetramethyl-pphenylenediamine.

\section{- SUPPLEMENTARY DATA}

To view the supplementary data that accompany this paper please visit the journal website at: www.future-science. com/doi/suppl/10.2144/btn-2018-0106

\section{REFERENCES}

Papers of special note have been highlighted as: • of interest

1. Heydari-Bafrooei E, Amini M, Saeednia S. Electrochemical detection of DNA damage induced by Bleomycin in the presence of metal ions. J. Electroanal. Chem. $\mathbf{8 0 3}$ 104-110 (2017).

2. Lin $\mathrm{XY}, \mathrm{Ni} \mathrm{YN}$, Kokot $\mathrm{S}$. An electrochemical DNA-senso developed with the use of methylene blue as a redox indicator for the detection of DNA damage induced by endocrine-disrupting compounds. Anal. Chim. Acta. 867, 29-37 (2015)

3. Fojta M, DaŇhel A, Havran L, VyskoČil V. Recent progress in electrochemical sensors and assays for DNA damage and repair. Trends Analyt. Chem. 79, 160-167 (2016).

4. Kelley SO, Boon EM, Barton JK, Jackson NM, Hill MG. Single-base mismatch detection based on charge transduction through DNA. Nucleic Acids Res. 27(24), 4830-4837 (1999).

5. Constantin Diculescu V, Chiorcea Paquim AM, Maria Oliveira Brett A. Electrochemical DNA sensors for detection of DNA damage. Sensors 5, 377-393 (2005).

- Detected the oxidized DNA base signal using differential pulse voltammetry method.

6. Bǔ̌ková M, Labuda J, Šandula J, Križková L, ŠtĚpánek I, DuraČková Z. Detection of damage to DNA and antioxidative activity of yeast polysaccharides at the DNA-modified screen-printed electrode. Talanta 56(5), 939-947 (2002).

7. Boon EM, Salas JE, Barton JK. An electrical probe of protein-DNA interactions on DNA-modified surfaces. Nat. Biotechnol. 20, 282-286 (2002).

- DNA-modified surface as a sensor for probing DNA interaction.

8. Hepel M, Stobiecka M, Peachey J, Miller J. Intervention of glutathione in pre-mutagenic catechol-mediated DNA damage in the presence of copper(II) ions. Mutat. Res. 735(1-2), 1-11 (2012).

9. Hepel M, Stobiecka M. Interactions of herbicide atrazin with DNA. Nova Science Publishers, NY, USA (2010).

10. Brabec V. DNA Sensor for the determination of antitumor platinum compounds. Electrochim Acta. 45 2929-2932 (2000)

11. Wang J, Chicharro $M$, Rivas $G$ et al. DNA biosensor for the detection of hydrazines. Anal. Chem. 68(13), 2251-2254 (1996)
12. Lucarelli F, Kicela A, Palchetti I, Marrazza G, Mascini $M$. Electrochemical DNA biosensor for analysis of wastewater samples. Bioelectrochemistry 8(1), 113-118 (2002)

13. Wang D, Lippard SJ. Cellular processing of platinum anticancer drugs. Nat. Rev. Drug Deliv. 4(4), 307-320 (2005).

14. Reedijk J. New clues for platinum antitumor chemistry Acad. Sci. USA 100(7), 3611-3616 (2003).

15. Rosenberg B, VanCamp L, Trosko JE, Mansour VH. Platinum compounds: a new class of potent antitumour agents. Nature 222(5191), 385-386 (1996).

16. Hambley TW. The influence of structure on the activity and toxicity of $\mathrm{Pt}$ anti-cancer drugs. Coord. Chem. Rev. 166, 181-223 (1997)

17. Raymond E, Faivre S, Chaney S, Woynarowski J, Cvitkovic E. Cellular and molecular pharmacology of oxaliplatin. Mol. Cancer Ther. 1(3), 227-235 (2002).

18. Xiao F, Luo $X$, Fu $X$, Zheng $Y$. Cleavage enhancement of specific chemical bonds in DNA by cisplatin radiosensitization. J. Phys. Chem. B. 117(17), 4893-4900 (2013).

19. Kalantari S, Wang CR, Lu QB. Electron transfer reaction mechanism of cisplatin with DNA at the molecular level. Mol. Pharm. 4(4), 624-628 (2007)

The proposal of the electron transfer mechanism of cisplatin.

20. Lu QB. Molecular reaction mechanisms of combination treatments of low-dose cisplatin with radiotherapy and photodynamic therapy. J. Med. Chem. 50(11), 2601-2604 (2007)

- The cisplatin combination therapy based on the electron transfer mechanism of cisplatin

21. Luo T, Yu J, Nguyen J et al. Electron transfer-based combination therapy of cisplatin with tetramethyl-P-phenylenediamine for ovarian, cervical, and lung cancers.
Proc. Natl Acad. Sci. USA 109(26), 10175-10180 (2012)

New cisplatin and electron donor-based combination chemotherapy designed through electron transfer mechanism.

22. Thomas DC, Morton AG, Bohr VA, Sancar A. General method for quantifying base adducts in specific mammalian genes. Proc. Natl Acad. Sci. USA 85(11), 3723-3727 (1988)

23. Singh NP, McCoy MT, Tice RR, Schneider EL. A simple technique for quantitation of low levels of DNA damage in individual cells. Exp. Cell Res. 175(1), 184-191 (1988)

24. England TG, Jenner A, Aruoma Ol et al. Determination of oxidative dna base damage by gas chromatography-mass spectrometry. Effect of derivatization conditions on artifactual formation of certain base oxidation products. Free Radic. Res. 29(4), 321-330 (1998).

25. Poirier MC, Reed E, Shamkhani $\mathrm{H}$ et al. Platinum drug-DNA interactions in human tissues measured by cisplatin-DNA enzyme-linked immunosorbent assay and atomic absorbance spectroscopy. Environ. Health Perspect. 99(13), 149-154 (1993). lar beacons. Chem. Pap. 69, 62-76 (2015). kinetically controlled metal binding to DNA. Proc. Nat

26. Stobiecka M, Chałupa A. Biosensors based on molecu-
27. Ilkhani $\mathrm{H}$, Hughes $\mathrm{T}$, Li J et al. Nanostructured SERS-electrochemical biosensors for testing of anticancer drug interactions with DNA. Biosens. Bioelectron. 80, 257-264 (2016).

28. KurzĄtkowska K, Santiago T, Hepel M. Plasmonic nanocarrier grid-enhanced Raman sensor for studies of anticancer drug delivery. Biosens. Bioelectron. 91 780-787 (2017).

29. Chen Z, Santoso I, Wang R et al. Surface transfer hole doping of epitaxial graphene using $\mathrm{MoO}_{3}$ thin film. Appl. Phys. Lett. 96, 213104 (2010).

30. Liu H, Liu Y, Zhu D. Chemical doping of graphene. J. Mater. Chem. 21(10), 3335-3345 (2011).

31. Chen W, Chen S, Dong CQ et al. Surface transfer P-type doping of epitaxial graphene. J. Am. Chem. Soc. 129(34), 10418-10422 (2007)

32. Giovannetti G, Khomyakov PA, Brocks G et al. Doping graphene with metal contacts. Phys. Rev. Lett. 101(2), 3-6 (2008)

33. Hummers WS, Offeman RE. Preparation of graphitic oxide. J. Am. Chem. Soc. 80(6), 1339-1339 (1958).

34. Kovtyukhova NI, Ollivier PJ, Martin BR et al. Layer-by-layer assembly of ultrathin composite films from micron-sized graphite oxide sheets and polycations. Chem. Mater. 11(3), 771-778 (1999).

35. Gao X, Tang XS. Effective reduction of graphene oxide thin films by a fluorinating agent: diethylaminosulfur trifluoride. Carbon 76, 133-140 (2014).

36. Gilje S, Kaner RB, Wallace GG et al. Processable aqueous dispersions of graphene nanosheets. Nat. Nanotechnol. 3(2), 101-105 (2008)

37. Stempkowska I, Ligaj M, Jasnowska J, Langer J, Filipiak M. Electrochemical response of oligonucleotides on carbon paste electrode. Bioelectrochemistry 70(2), 488-494 (2007)

38. Egdell R, Green JC, Rao CNR. Photoelectron spectra of substituted benzenes. Chem. Phys. Lett. 3(3), 600-607 (1975)

39. Hirata $Y$, Mataga N. Monophotonic ionization from the vibrationally unrelaxed excited singlet state of $\mathrm{N}, \mathrm{N}, \mathrm{N}^{\prime}, \mathrm{N}^{\prime}$-tetramethyl-P-phenylenediamine in acetonitrile solution. J. Phys. Chem. 94(10), 3872-3874 (1990).

40. Herne TM, Tarlov MJ. Characterization of DNA probes immobilized on gold surfaces. J. Am. Chem. Soc 119(38), 8916-8920 (1997).

41. Xu Z, Wang S, Li Y et al. covalent functionalization of graphene oxide with biocompatible poly(ethylene glycol) for delivery of paclitaxel. ACS Appl. Mater. Interfaces 6(19), 17268-17276 (2014)

42. Souza LAD, Nogueira CAS, Lopes JF et al. Theoretical study of the formation of inclusion complex between cisplatin and single-wall carbon nanotube. J. Phys. Chem. C. 119(15), 8394-8401 (2015).

The interaction between cisplatin and carbon nano materials. 